\title{
EFFECT OF COMMERCIAL SILANES ON BOND STRENGTH OF RESIN CEMENT TO LITHIUM DISILICATE CERAMIC
}

\author{
EFEITO DE SILANOS COMERCIAIS NA RESISTÊNCIA DE UNIÃO DO CIMENTO \\ RESINOSO À CERÂMICA DE DISSILICATO DE LÍTIO
}

\author{
Jamille FAVARÃ̃ ${ }^{1}$; Maurício Matté ZANINI ${ }^{1}$; Guilherme Bottene GUARDA $^{2}$; \\ Marcio José MENDONÇA ${ }^{3}$; Mário Alexandre Coelho SINHORETI²; \\ Simonides CONSANI ${ }^{2}$; Eliseu Augusto SICOLI ${ }^{3}$
}

1. Centro Universitário Dinâmica das Cataratas, Faculdade de Odontologia, Foz do Iguaçu, PR, Brasil. jamillefavarao@hotmail.com; 2. Universidade Estadual de Campinas, Faculdade de Odontologia de Piracicaba, Piracicaba, SP, Brasil. 3- Universidade Estadual do Oeste do Paraná, Faculdade de Odontologia, Cascavel, PR, Brasil.

\begin{abstract}
The aim of this study was to evaluate the effect of different commercial silanes on microshear bond strength of resin cement to lithium disilicate ceramic. Twenty ceramic samples with $10 \mathrm{~mm}$ in length, $10 \mathrm{~mm}$ wide and $3 \mathrm{~mm}$ in thickness were fabricated, etched with $10 \%$ hydrofluoric acid for 20 seconds, and divided into 5 groups, according to the commercial silane applied: G1- RelyX Ceramic Primer (3M ESPE), G2- Angelus Silane, G3- Prosil (FGM), G4- Dentsply Silane (Dentsply) and G5- Bis-Silane (Bisco). Silanes were applied in accordance to manufacturers' recommendations. Addition silicone molds with $1 \mathrm{~mm}$ in thickness, $10 \mathrm{~mm}$ in diameter and 3 perforations with $1 \mathrm{~mm}$ in diameter each one, were placed on ceramic and filled with the resin cement RelyX ARC (3M ESPE) in all groups. Light activation was performed with LED Bluephase G2 (Ivoclar Vivadent) at $1200 \mathrm{~mW} / \mathrm{cm}^{2}$, for 30 seconds. Samples were maintained in $100 \%$ humidity at $37^{\circ} \mathrm{C}$ for 24 hours and submitted to microshear test. The data (MPa) were submitted to one-way ANOVA and Tukey test $(\alpha=0.05)$. The results obtained for each group were: G1: $22.39 \pm 2.99$; G2: $23.35 \pm 4.08$; G3: 26.05 \pm 5.46 ; G4: 18.56 \pm 4.09 ; G5: $25.26 \pm 4$.10. Statistical analysis showed significantly lower microshear bond strength for G4. Fracture pattern analysis showed predominance of adhesive failures in G1 and G2. G3 and G5 presented higher percentage of cohesive failures in ceramic, and G4 showed mixed, adhesive and cohesive fractures with similar percentages. It was concluded that different silanes showed influence on the lithium disilicate ceramic - resin cement bond strength.
\end{abstract}

KEYWORDS: Silanes. Ceramics. Cementation. Shear strength.

\section{INTRODUCTION}

Ceramics have increasingly become the best option of esthetic restoration of dental structures. The factors that have contributed to the choice of this material are mechanical strength, biocompatibility and esthetics (ZOGHEIB et al., 2011; WONG et al., 2017; KESHVAD; HAKIMANEH, 2018). Current ceramic systems include lithium disilicate, glass infiltrated alumina and zirconia, and high-density alumina or zirconia ceramic systems (SANTOS et al., 2015).

Ceramic systems, which contain high strength materials such as zirconia, can be fixed with conventional cement. Silica-based ceramic systems, such as lithium disilicate, are routinely cemented by the adhesive technique through resin cements (ATTIA, 2011; ZORTUK et al., 2010; GARBOZA et al., 2016). These resin cements present some advantages when compared to the zinc phosphate cement, as a higher resistance to compression, low solubility, and also better elastic modulus (around $8 \mathrm{GPa}$ ) (BORGES et al., 2003).

For proper bonding of the lithium disilicate ceramic to the dental structure it is necessary the ceramic conditioning with hydrofluoric acid and silane application. The acid reacts selectively with the glass matrix containing silica and removes it, exposing the crystalline structure. The surface energy is increased, improving the ceramic interaction with the luting cement (TRIBST et al., 2018). On the other hand, zirconia and aluminumbased ceramic have a high crystalline content, making this material more resistant to etching with hydrofluoric acid (ZOGHEIB et al., 2011; NAVES et al., 2010).

Researches have revealed that silanization is really effective in increasing the bond strength between conditioned ceramic and resin cement (ATTIA, 2010; LISE et al., 2015; MORO et al., 2017). The silane used in dentistry is 3methacryloxypropyltrimethoxysilane that is composed of organic radicals and water soluble 
monovalent groups (KALAVACHARLA et al., 2015; YAO et al., 2017).

Before application, silane coupling agents must be hydrolyzed (chemically activated) by acid catalyst. Their hydrolyzable alkoxy groups are allowed to react in aqueous alcohol solution, at a $\mathrm{pH}$ of 4-5, with hydroxyl groups $(-\mathrm{OH})$ present on the ceramic surface and with the methacrylate group present in bonding agent or resin cement (KALAVACHARLA et al., 2015; MATINLINNA; LASSILA; VALLITTU, 2007).

There are different types of silane, some are presented in a single bottle, in which they have already been hydrolyzed, and others are packed in two bottles and hydrolysis occurs at the time of mixing their contents (SPOHR et al., 2003).

Therefore, the aim of this study was to evaluate the effect of the application of different commercial brands of silane on the bond strength between lithium disilicate ceramic and resin cement. The hypothesis was that the use of different silanes would affect the bond strength of lithium disilicate ceramic to resin cement.

\section{MATERIAL AND METHODS}

\section{Ceramic specimens fabrication}

Twenty specimens with $10 \mathrm{~mm}$ in length, $10 \mathrm{~mm}$ wide and $3 \mathrm{~mm}$ in thickness were prepared using IPS e.max Press ceramic system (Ivoclar Vivadent, Schaan, Liechtenstein), shade LT A2, following the manufacturer's instructions. These samples were divided in 5 groups, according to the commercial silane used (Table 1).

Table 1. Experimental groups.

\begin{tabular}{lll}
\hline Group & Silane & Manufacturer and Lot Number \\
\hline G1 & RelyX Ceramic Primer & 3M ESPE, St. Paul, MN,USA \\
& & Lot: 9YY \\
G2 & Angelus, Londrina, Pr, Brazil \\
& Lot: 18958 \\
G3 & Prosil & FGM, Joinville, SC, Brazil \\
& & Lot: 260511 \\
G4 & Denstply Silane & Denstply, Petropolis, RJ, Brazil \\
& Lot: 5160570 \\
G5 & Bis-Silane & Bisco, Schaumburg, IL, USA \\
& & Lot: 1100001391 \\
\hline
\end{tabular}

\section{Ceramic Surface Treatments}

The ceramic surface was etched with $10 \%$ hydrofluoric acid (FGM, Joinville, SC, Brazil.) for 20 seconds at room temperature $\left(24 \pm 2^{\circ} \mathrm{C}\right)$, and then and rinsed with air-water spray for 1 minute.

\section{Silanization Procedure}

After cleaning and drying the ceramic surface, the silane was applied according to the manufacturers' recommendations, as follows:

G1 - One coat of RelyX Ceramic Primer (3M ESPE, St. Paul, MN,USA) was applied and rubbed using a microbrush on etched ceramic, and drying with jets of air for 5 seconds;

G2 - One coat of Angelus Silane (Angelus, Londrina, Pr, Brazil) was applied and rubbed using a microbrush on etched ceramic, allowed air-dry for 1 minute, and drying with light jets of air for 5 seconds;

G3 - One coat of Prosil (FGM, Joinville, SC, Brazil) was applied and rubbed using a microbrush on etched ceramic, allowed air-dry for 1 minute, and drying with light jets of air for 5 seconds;

G4 - One drop of Primer and 1 drop of Denstply Silane (Denstply, Petropolis, RJ, Brazil) were mixed with microbrush for 15 seconds. After 5 minutes, one coat of silane was applied, rubbed, and dried with light jets of air for 5 seconds. Afterwards, a second coat was applied and dried in the same mode;

G5 - One drop from bottle A and one drop from bottle B of Bis-Silane (Bisco, Schaumburg, IL, USA) were mixed. A thin coat was applied to the surface, rubbed with a microbrush, waiting for 30 seconds, and drying with light jets of air to evaporate the solvent.

\section{Application of resin cement}

An addition silicone mold (Express, 3M ESPE, St. Paul, MN, USA) with $1 \mathrm{~mm}$ in thickness and $10 \mathrm{~mm}$ in diameter, containing three cylindrical orifices with $1 \mathrm{~mm}$ in diameter each one, was placed 
on the ceramic surface to constitute the cementation sites used in the microshear bond strength test.

After, $10 \mu \mathrm{L}$ of dual-cure resin cement RelyX ARC (3M ESPE, St. Paul, MN, USA) were carefully inserted into silicone mold orifices, covered with a polyester strip, and kept under finger pressure for 30 seconds. The resin cement was lightcured for 30 second with a LED curing light unit (Bluephase G2, Ivoclar Vivadent, Schaan, Liechtenstein) with an irradiance of 1,200 $\mathrm{mW} / \mathrm{cm}^{2}$. After light-curing, the silicone mold was cut with a scalpel blade and removed. The cylinder samples were stored in $100 \%$ relative humidity at $37^{\circ} \mathrm{C}$ for 24 hours.

\section{Microshear test}

The samples were submitted to the microshear bond strength test in a universal test machine (Instron, model 4411, London, England). Each cylinder sample was placed in the orifice of a metal sleeve. A thin stainless steel wire $(0.2 \mathrm{~mm}$ in diameter) was looped around the base of each cylinder and aligned with the bonding interface and subjected to a crosshead speed of $0.5 \mathrm{~mm} / \mathrm{min}$ until failure.

\section{Fracture analysis}

The failure mode of the samples was observed under an optical microscope (Leika Microsystems, Wetzar, Germany) at 40x magnification. The failure mode was classified as: adhesive, cohesive in ceramic, cohesive in cement and mixed (resin cement and ceramic).

\section{Statistical analysis}

The Shapiro-Wilk test was applied to assess normal data distribution. The data were analyzed by one-way ANOVA and Tukey's test for comparisons among the different groups. Statistical significance was established at $\alpha=0.05$ for all tests.

\section{RESULTS}

The microshear bond strength means are shown in Table 2. A statistically significant difference $(p<0.05)$ was found for the G4, with lower value when compared to the others, which showed no difference among them $(\mathrm{p}>0.05)$.

Table 2. Mean (MPa) and Standard Deviation of ceramic-resin cement shear bond strength.

\begin{tabular}{ll}
\hline Group & Mean \pm Standard Deviation \\
\hline G1 - RelyX Ceramic Primer & $22.39 \pm 2.99 \mathrm{a}$ \\
G2 - Angelus Silane & $23.35 \pm 4.08 \mathrm{a}$ \\
G3 - Prosil & $26.05 \pm 5.46 \mathrm{a}$ \\
G4 - Dentsply Silane & $18.56 \pm 4.09 \mathrm{~b}$ \\
G5 - Bis-Silane & $25.26 \pm 4.10 \mathrm{a}$ \\
\hline
\end{tabular}

Different letters indicate statistically significant difference.

Figure 1 shows the failure mode analysis (\%). G1 and G2 presented predominance of adhesive failures. G3 and G5 presented higher cohesive failures in ceramic and G4, mixed failures, adhesive and cohesive in ceramic, with similar values.

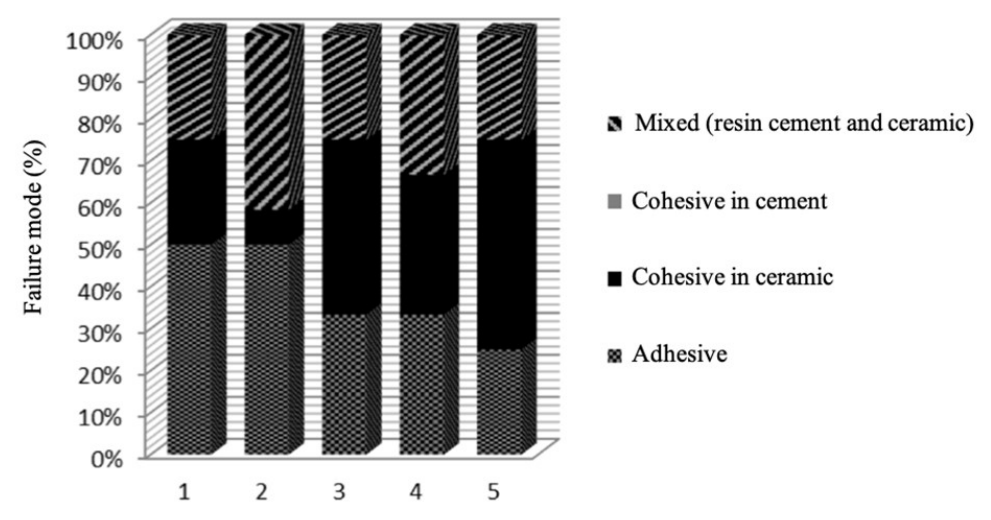

Figure 1. Graphic illustration of the failure mode analysis. 


\section{DISCUSSION}

The results of this study confirmed the hypothesis that different silanes affect the bond between lithium disilicate ceramic and resin cement when submitted to microshear test. In addition to the chemical adhesion, the silane also improves the mechanical bonding, since it increases the surface wettability, improving contact and infiltration of the cements into the ceramics irregularities (CARVALHO et al., 2011; KAIMAL et al., 2017).

Different silanes can cause different effects and their effectiveness may vary according to the degree of hydrolysis. The higher the degree of hydrolysis, the better will be the bond provided by silane because it can promote a high degree of siloxane bonding to silica. This siloxane bond results in better chemical adhesion of the resin cement to ceramic (KAIMAL et al., 2017; UMEMOTO; KURATA, 1995).

Furthermore, some silanes have a better ability to wet the ceramic surface. In contrast, water infiltration at the silane - ceramic interface may have an influence on the level of degradation and bond strength between resin and ceramic cement (SPOHR et al., 2003). The silanes used in this study have basically the same chemical composition, according to the information provided by the manufacturers. Thus, it can be considered that the statistical difference between group 4 and the other groups is due to the form of application recommended by the manufacturer. This fact can be explained by the chemical nature of the silane and the way the solvent evaporates.

According to Barghi (2000), after silanization the waiting time necessary for performing cementation would be 3 minutes. The silane contains ethanol as solvent in the formulation, and the way its evaporation occurs after application, can provide different bond strength values. However, prolonged exposure of the silanized surface to the environment could also impair the bonding; thus, silanization should be performed "immediately" prior to restoration cementation (BARGHI, 2000).

Group 4, according to the manufacturer's instructions, was the only one that received 2 coats of silane and which did not have a waiting time before drying or a determined time of drying with jets of air. This factor may have allowed less evaporation of solvent and less silane-silica reaction. This fact did not occur in the other groups, in which the manufacturers' instructions recommended a waiting time or a determined time of drying after the silane application.

Hooshmand et al. (2002) observed, after the application and drying of the silane, the presence of an interface with three structures: 1- An external layer composed of small oligomers. This layer is absorbed by the glass, but is capable of being removed by organic solvents or by water at ambient temperature. 2- An intermediate layer composed of similar oligomers, linked by siloxane bridges. 3- A deeper layer, which represent a larger number and uniformity of the crossed links, forming a regular tridimensional, more hydrolytically stable network. In the study, they stated that only the deepest and stable layer would be required to improve adhesion and that the elimination of the most external layer of silane could improve the bond. Based on this assertion it may be suggested that in groups 1, 2, 3 and 5 there was selective removal of the external layer and maintenance of the deepest layer, which improved the bond strength in these groups.

In this study the fracture analysis showed that group 4 presented adhesive, cohesive, and mixed fractures, suggesting that there is no predictable behavior in this group. This may have occurred due to the presence of solvent in the interface causes instability in the union. Groups 3 and 5 presented a higher percentage of cohesive failures in ceramics, which suggests higher union strength, in agreement with study by Tsukakoshi et al. (2008). Although groups 1 and 2 do not present a statistically significant difference in relation to groups 3 and 5 , clinically they can present a favorable fracture pattern, since they do not involve the prosthetic element.

However, since the tests were conducted to evaluate only one ceramic surface bonded to the resin cement, it is not possible to predict how would be the behavior of these materials when applied in the cementation of onlay restorations. As in this type of restoration the C-factor is higher, there could be an increase in polymerization shrinkage stress, causing reduction in the longevity of the bond between ceramic and resin cement.

\section{CONCLUSION}

Different silanes showed influence on the lithium disilicate ceramic-resin cement bond strength, since the silanes RelyX Ceramic Primer, Angelus Silane, Prosil and Bis-Silane showed similar microshear bond strength among them and were better than Dentsply Silane. 
RESUMO: O objetivo neste estudo foi avaliar o efeito de diferentes silanos comerciais na resistência de união ao microcisalhamento do cimento resinoso à cerâmica de dissilicato de lítio. Foram confeccionadas 20 amostras de cerâmica $(10 \mathrm{~mm}$ de comprimento, $10 \mathrm{~mm}$ de largura e $3 \mathrm{~mm}$ de espessura), condicionadas com ácido fluorídrico a 10\% por 20 segundos e divididas em 5 grupos, de acordo com o silano aplicado: G1- RelyX Ceramic Primer (3M ESPE), G2- Silano Angelus, G3-Prosil (FGM), G4- Silano Dentsply e G5-Bis-Silane (Bisco). Matrizes de silicone por adição (1 mm de espessura, $10 \mathrm{~mm}$ de diâmetro e 3 perfurações com $1 \mathrm{~mm}$ de diâmetro) foram colocadas sobre a cerâmica e preenchidas com cimento resinoso RelyX ARC (3M ESPE). A fotoativação foi realizada com LED Bluephase G2 (Ivoclar Vivadent) a $1200 \mathrm{~mW} / \mathrm{cm}^{2}$, por 30 segundos. As amostras foram mantidas em $100 \%$ de umidade a $37^{\circ} \mathrm{C}$ por 24 horas e submetidas ao teste de microcisalhamento. Os dados (MPa) (G1: 22,39+2,99; G2: 23,35+4,08; G3: 26,05+5,46; G4: 18,56+4,09; G5: $25,26 \pm 4,10)$ foram submetidos a análise de variância e ao teste de Tukey $(\mathrm{p}<0,05)$. A análise estatística mostrou valor de resistência de união significantemente menor para G4. A análise do padrão de fratura mostrou predominância de falha adesiva para G1 e G2. G3 e G5 apresentaram maior porcentagem de falha coesiva em cerâmica, e o G4 apresentou fraturas mista, adesiva e coesiva em igual porcentagem. Concluiu-se que os diferentes silanos apresentaram influência na resistência de união do cimento resinoso à cerâmica de dissilicato de lítio.

PALAVRAS-CHAVE: Silanos. Cerâmica. Cimentação. Resistência ao Cisalhamento.

\section{REFERENCES}

ATTIA, A. Influence of surface treatment and cyclic loading on the durability of repaired all-ceramic crowns. J Appl Oral Sci, v. 18, n. 2, p. 194-200, Mar-Apr. 2010. https://doi.org/10.1590/S1678-77572010000200015

ATTIA, A. Bond strength of three luting agents to zirconia ceramic - influence of surface treatment and thermocycling. J Appl Oral Sci, v. 19, n. 4, p. 388-395, Aug. 2011. https://doi.org/10.1590/S167877572011005000015

BARGHI, N. To silanate or not silanate: making a clinical decision. Compend Contin Educ Dent, v. 21, n. 8, p. 659-662, Aug. 2000.

BORGES, G. A.; SPOHR, A. M.; GOES, M. F.; SOBRINHO, L. C.; CHAN, D. C. N. Effect of etching and airborne particle abrasion on the microstructure of different dental ceramics. J Prosthet Dent, v. 89, n. 5, p. 479-488, May. 2003. https://doi.org/10.1016/S0022-3913(02)52704-9

CARVALHO, R. F.; MARTINS, M. E.; DE QUEIROZ, JR.; LEITE, F. P.; ÖZCAN, M. Influence of silane heat treatment on bond strength of resin cement to a feldspathic ceramic. Dent Mater, v. 30, n. 3, p. 392-397, May. 2011. https://doi.org/10.4012/dmj.2010-137

GARBOZA, C. S.; BERGER, S. B.; GUIRALDO, R. D.; EUGOLIN, A. P.; GONINI-JÚNIOR ,A.; MOURA, S. K.; LOPES,M. B. Influence of surface treatments and adhesive systems on lithium disilicate microshear bond strength. Braz Dent J, v. 27, n. 4, p. 458-462, Jul-Aug. 2016. https://doi.org/10.1590/01036440201600624

HOOSHMAND,T.; VAN NOORT, R.; KESHVAD, A. Bond durability of the resin bonded and silane treated ceramic surface. Dent Mater, v. 18, n. 2, p. 179-188, Mar. 2002. https://doi.org/10.1016/S01095641(01)00047-1

KAIMAL, A.; RAMDEV, P.; SHRUTHI, C. S. Evaluation of effect of zirconia surface treatment, using plasma of argon and silane, on the shear bond strength of two composite resin cements. Journal of Clin and Diagn Res, v. 11, n. 8, p. ZC39-ZC43, Aug. 2017. https://doi.org/10.7860/JCDR/2017/27426.10372 
KALAVACHARLA, V. K.; LAWSON N,. C.; RAMP, L. C.; BURGESS, J. O. Influence of etching protocol and silane treatment with a universal adhesive on lithium disilicate bond strength. Oper Dent, v. 40, n. 4, p. 372-378, Jul-Aug. 2015. https://doi.org/10.2341/14-116-L

KESHVAD, A.; HAKIMANEH, S. M. R. Microtensile bond strength of a resin cement to silica-based and ytzp ceramics using different surface treatments. J Prosthodont, v. 27, n. 1, p. 67-74, Jan. 2018.

https://doi.org/10.1111/jopr.12622

LISE, D.P.; PERDIGÃO, J.; VAN ENDE, A.; ZIDAN, O.; LOPES, G. C. Microshear bond strength of resin cements to lithium disilicate substrates as a function of surface preparation. Oper Dent, v. 40, n. 5, p. 524-532, Sep-Oct. 2015. https://doi.org/10.2341/14-240-L

MATINLINNA, J. P.; LASSILA, L. V. J.; VALLITTU, P. K. The effect of five silane coupling agents on the bond strength of a luting cement to a silica-coated titanium. Dent Mater, v. 23, n. 9, p. 1173-1180, Sep. 2007. https://doi.org/10.1016/j.dental.2006.06.052

MORO, A. F. V.; RAMOS,A. B.; ROCHA, G. M.; PEREZ, C. D. R. Effect of prior silane application on the bond strength of a universal adhesive to a lithium disilicate ceramic. J Prosthet Dent, v. 118, n. 5, p. 666-671, Nov. 2017. https://doi.org/10.1016/j.prosdent.2016.12.021

NAVES, L. Z.; SOARES, C. J.; MORAES, R. R.; GONÇALVES, L. S.; SINHORETI, M. A.; CORRERSOBRINHO, L. Surface/interface morphology and Bond strength to glass ceramic etched for different periods. Oper Dent, v. 35, n. 4, p. 420-427, Jul-Aug. 2010. https://doi.org/10.2341/09-152-L

SANTOS, M. J.; COSTA, M. D.; RUBO, J. H.; PEGORARO, L. F.; SANTOS, G. C. Current all-ceramic systems in dentistry: a review. Compend Conti Educ Dent, v. 36, n. 1, p. 31-37, Jan. 2015.

SPOHR, A. M.; SOBRINHO, L. C.; CONSANI, S.; SINHORETI,M. A.; KNOWLES, J. C. Influence of surface conditions and silane agent on the bond of resin to IPS Empress 2 ceramic. Int J Prosthodont, v. 16, n. 3, p. 277-282, May-Jun. 2003.

TRIBST, J.; ANAMI, L. C.; OZCAN, M.; BOTTINO, M. A.; MELO, R. M.; SAAVEDRA, G. Self-etching primers vs acid conditioning: impact on bond strength between ceramics and resin cement. Oper Dent, v. $43, \mathrm{n}$. 4, p. 372-379, Jul-Aug. 2018. https://doi.org/10.2341/16-348-L

TSUKAKOSHI, M.; SHINYA, A.; GOMI, H.; LASSILA, V. J.; VALLITTU, P.; SHINYA, A. Effects of dental adhesive cement and surface treatment on bond strength and leakage or zirconium oxide ceramics. Dent Mater J, v. 27, n. 2, p. 159-171, Mar. 2008. https://doi.org/10.4012/dmj.27.159

UMEMOTO, K.; KURATA, S. Effects of mixed silane coupling agent on porcelain tooth material and various dental alloys. Dent Mat J, v. 14, n. 2, p. 135-142, Dec. 1995. https://doi.org/10.4012/dmj.14.135

WONG, A. C. H.; TIAN, T.; TSOI, J. K. H.; BURROW, M. F.; MATINLINNA, J. P.; Aspects of adhesion tests on resin-glass ceramic bonding. Dent Mater, v. 33, n. 9, p. 1045-1055, Sep. 2017.

https://doi.org/10.1016/j.dental.2017.06.013

YAO, C.; ZHOU, L.; YANG, H.; WANG, Y.; SUN, H.; GUO, J.; HUANG, C. Effect of silane pretreatment on the immediate bonding of universal adhesives to computer-aided design/computer-aided manufacturing lithium disilicate glass ceramics. Eur J oral Sci, v. 125, n. 2, p. 173-180, Apr. 2017. https://doi.org/10.1111/eos.12340

ZOGHEIB, L. V.; DELLA, BONA, A; KIMPARA, E. T.; MCCABE, J. F. Effect of hydrofluoric acid etching duration on the roughness and flexural strength of a lithium disilicate based glass ceramic. Braz Dent $\mathbf{J}$, v. 22, n. 1, p. 45-50, 2011. https://doi.org/10.1590/S0103-64402011000100008

ZORTUK, M.; KILIC, K.; GURBULAK, A. G.; KESIN, B.; UCTASLI, S. Tensile Bond strength of a lithiumdisilicate pressed glass ceramic to dentin of different surface treatments. Dent Mater J, v. 29, n. 4, p. 418-424, Aug. 2010. https://doi.org/10.4012/dmj.2009-074 